\title{
Reversing the Soviet Economic Collapse
}

\section{Citation}

Shleifer, Andrei, and Robert W Vishny. 1991. Reversing the Soviet Economic Collapse. Brookings Papers on Economic Activity 22, no. 2: 341-367.

\section{Published Version}

https://www.brookings.edu/wp-content/uploads/1991/06/1991b_bpea_shleifer_vishny.pdf

\section{Permanent link}

http://nrs.harvard.edu/urn-3:HUL.InstRepos:30723290

\section{Terms of Use}

This article was downloaded from Harvard University's DASH repository, and is made available under the terms and conditions applicable to Other Posted Material, as set forth at http:// nrs.harvard.edu/urn-3:HUL.InstRepos:dash.current.terms-of-use\#LAA

\section{Share Your Story}

The Harvard community has made this article openly available.

Please share how this access benefits you. Submit a story.

\section{Accessibility}




\section{ANDREI SHLEIFER}

Harvard University

ROBERT W. VISHNY

University of Chicago

\section{Reversing the Soviet Economic Collapse}

THE SOVIET ECONOMY is collapsing. In 1990, official gross national product had fallen 2 percent relative to 1989 . By the first quarter of 1991, GNP had fallen 8 percent relative to a year earlier. Moreover, as table 1 illustrates, the decline has spread to just about every sector, from processed food, to consumer durables, to energy and agriculture. Many observers expect this decline to continue through 1991-even to accelerate. ${ }^{1}$ Such a sharp contraction is unprecedented in the postwar Soviet economy, which historically has grown moderately and without sharp interruptions.

In August 1991, the Soviet Union collapsed politically as well, splitting into a number of sovereign states with highly uncertain future economic ties. In the face of this uncertainty, the central government and the republics are contemplating reform policies designed to reverse the economic collapse. In this paper, we analyze the causes of the decline and discuss what reforms are appropriate and how to achieve them.

The decline of the Soviet economy is sometimes explained by exogenous shocks, like the troubles in the oil industry, the coal strike in the first quarter of 1990, the collapse of trade with Eastern Europe following its liberation, the plant shutdowns for environmental reasons, and the regional frictions in the USSR. All of these factors doubtless play a role,

[Much of the data presented in this paper were assembled by the authors from a variety of Soviet sources. Care has been taken to verify their consistency with the original sources. They should nonetheless be used with caution.-Eds.]

1. PlanEcon Report (1991, nos. 11-12). 
Table 1. Changes in Output, 1989-91

Percent

\begin{tabular}{lcc}
\hline \multicolumn{1}{c}{ Item } & $\begin{array}{c}\text { Change from } \\
\text { 1989 }\end{array}$ & $\begin{array}{c}\text { Change from } \\
\text { 1990:1 }\end{array}$ \\
\hline Gross national product & -2 & -8 \\
Total industry & -1 & -5 \\
Automobiles & 3 & -4 \\
Bath soap & 1 & -9 \\
Beef and fowl & -1 & -12 \\
Bread & 3 & 14 \\
Cement & 2 & -5 \\
Coal & -5 & -18 \\
Color televisions & 13 & 4 \\
Eggs & -4 & -8 \\
Electric energy & 0 & 1 \\
Farm equipment & -7 & -25 \\
Farm goods & -2 & -13 \\
Fertilizer & -8 & -8 \\
Gas & 2 & 0 \\
Kitchen soap & -3 & -18 \\
Milk & 0 & -10 \\
New housing & -11 & -27 \\
Oil & -6 & -9 \\
Paper & 3 & -6 \\
Processed meat & -3 & -14 \\
Steel & -4 & -8 \\
Sugar & -7 & -21 \\
\hline
\end{tabular}

Source: Ekonomika i zhizn' (1991, nos. 5 and 17). The output of farm goods is measured using real prices. The output of all other goods is measured using volumes.

but none is completely persuasive. Oil and coal production have indeed declined (see table 1), but many sectors that are not heavy users of these inputs have also suffered. Plant shutdowns resulting from environmental concerns have accelerated but are too few to materially affect output. Trade with Eastern Europe diminished 25 percent in 1990, and much more sharply in 1991, yet the beginnings of the Soviet downturn are often traced to 1988 and 1989, when trade with Eastern Europe was still strong. And frictions in regional trade in the former Soviet Union are not an exogenous shock. Rather, they reflect the widespread refusal of many firms to produce and trade at state prices. Lithuanians are refusing to sell meat to the Russians at state prices not just because they hate the Russians but also because state prices are too low. Russian farmers as 
well are refusing to sell meat at state prices. In short, exogenous shocks alone do not adequately explain Soviet problems.

We believe that the decline in Soviet output can be better explained by the combination of severe repressed inflation and substantial liberalization of plan enforcement since 1988. This combination of repressed inflation, which greatly distorted incentives, with partial liberalization, which completely undermined plan enforcement, led to a breakdown of traditional economic ties and coordination mechanisms in the Soviet economy. In particular, we focus on three channels of the breakdown. First, repressed inflation diverted labor away from productive activities and into search for goods, thus reducing effective labor input. Second, repressed inflation combined with productive freedom made it attractive for enterprises to hoard intermediate inputs, leading to declines in output and breakdowns in downstream production. Third, repressed inflation combined with the freedom to choose trading partners led firms to resell or barter their output to higher-paying customers, leaving their traditional customers without supplies and so reducing production downstream. For all three channels of the breakdown, we present evidence of the magnitude of the problem.

We then discuss what our diagnosis of Soviet problems may mean for economic reform and Western aid. Like many others, we argue that rapid price liberalization is the only alternative to rigid planning if normal economic coordination is to be restored in the Soviet economy. Such price liberalization is particularly important in intermediate-goods markets, in which price distortions are largely responsible for the economic collapse. We also argue that aid from the West should be tightly conditioned on price liberalization and other policies that foster trade, with heavy penalties for policies that preclude the movement of resources. In fact, Western donors should encourage competition for aid between the republics by awarding funds to those that liberalize and denying them to those that do not.

\section{Repressed Inflation and Shortages}

Several studies have documented the recent Soviet inflation and the extensive shortages. ${ }^{2}$ This brief section reviews and updates that work.

2. International Monetary Fund and others (1991); Åslund (1991). 
Table 2. Inflation in the USSR, 1980-91

Percent

\begin{tabular}{lccccr}
\hline Year & $\begin{array}{c}\text { Official } \\
\text { inflation }\end{array}$ & $\begin{array}{c}\text { Income } \\
\text { growth }\end{array}$ & $\begin{array}{c}\text { Expenditure } \\
\text { growth }\end{array}$ & $\begin{array}{c}\text { Money } \\
\text { supply } \\
\text { growth }\end{array}$ & $\begin{array}{c}\text { Farmers' } \\
\text { market } \\
\text { inflation }\end{array}$ \\
\hline 1980 & 1.0 & 5.2 & 4.6 & $\ldots$ & 14.1 \\
1981 & 1.0 & 4.3 & 5.0 & $\ldots$ & 9.1 \\
1982 & 4.0 & 4.2 & 3.4 & $\ldots$ & -1.1 \\
1983 & 0.0 & 4.8 & 4.7 & $\ldots$ & -3.9 \\
1984 & -1.0 & 3.8 & 3.9 & $\ldots$ & 2.8 \\
1985 & 1.0 & 3.7 & 3.7 & $\ldots$ & 3.5 \\
1986 & 2.0 & 3.6 & 3.7 & 6.1 & -3.6 \\
1987 & 1.3 & 3.9 & 3.5 & 7.8 & 2.6 \\
1988 & 0.6 & 9.2 & 8.5 & 13.6 & 2.6 \\
1989 & 2.0 & 12.9 & 11.6 & 19.5 & 9.5 \\
1990 & 5.3 & 16.9 & 15.2 & 21.5 & 29.0 \\
$1991: 1$ (relative to 1990:1) & $\ldots$ & 24.0 & 24.0 & $\ldots$ & 71.0 \\
\hline
\end{tabular}

Sources: Official inflation figures are from PlanEcon Report (1991). Income growth for 1980-89 was provided by the IMF. Income figures for 1990 and 1991 come from Gaidar (1991) and Ekonomika i zhizn' (1991, no. 17), respectively. Expenditure growth for 1980-89 comes from IMF and others (1991) and Ekonomika i zhizn' (1991, no. 17). Money supply growth comes from IMF and others (1991) and Gaidar (1991); cumulative money supply growth for 1980-85 was 6 percent. Farmers' market prices are from Narodnoye Khoziaistvo SSSR, Torgovlia SSSR, and Ekonomika i zhizn' (1991, no. 6).

The image that emerges is one of a severe repressed inflation, a condition that worsened in 1990 and the first quarter of 1991. We have much less information about the period after the April 1 price reform, but the available data suggest that shortages have not been cured.

The first column of table 2 presents changes in the official Soviet price index, which is also used in the International Monetary Fund-World Bank study. The index shows no substantial price increases during the 1980s and inflation of only 5.3 percent in 1990. The 1991 index has not yet been made available, but official prices had not risen substantially until the April 1 retail price reform. By contrast, the next three columns show the growth of income, expenditure, and the money supply. The series reveal a sharp increase in the growth rates of all these variables starting in 1988. The preliminary data on the first quarter of 1991 show accelerating growth, with both income and expenditure about 24 percent higher than the first quarter of 1990 . The central government budget deficit in the first quarter of 1991 was the largest ever and, if anything, the growth of the money supply has probably accelerated. ${ }^{3}$

3. PlanEcon Report (1991, nos. 11-12). 
Table 3. Commersant Monthly Inflation, 1990 and 1991 Percent

\begin{tabular}{lr}
\hline Month & Inflation \\
\hline 1990 & 1.2 \\
July & 0.8 \\
August & 2.8 \\
September & $\ldots$ \\
October & 3.1 \\
November & 4.5 \\
December & \\
1991 & 4.5 \\
January & 5.1 \\
February & 52.0 \\
March & 170.0 \\
April &
\end{tabular}

Source: Commersant, various issues. The table shows the increase in average living costs from Commersant's monthly survey of prices in major cities.

Given the growth of money and income, and the rigidity of official prices, it is not surprising that a severe repressed inflation has developed. One way to observe it is by comparing free market prices with state prices. The last column of table 2 shows inflation in the farmers' market, which rose from a sharp 9.5 percent in 1989 to 29.0 percent in 1990 and 71.0 percent over the 1990:1-1991:1 period. Since official food prices did not change at all during this period, inflation of the farmers' market prices also reflects the relative change in market and official prices and thus the magnitude of repressed inflation. These series show clearly that repressed inflation worsened in 1990 and was particularly bad in the beginning of 1991 .

Table 3 shows the month-to-month increases in the Commersant aggregate cost-of-living index, which reflects both state and free market prices. This index has the advantage of providing very recent information. It shows prices rising by about 5 percent a month around the turn of the year, 52 percent in March, in anticipation of the price reform, and 170 percent in April when official prices were raised.

Another way to measure repressed inflation uses market exchange rates taken from the black market and from state currency auctions open to enterprises. Table 4 presents the two series, which show surprising conformity. Since the beginning of 1990 , the ruble has depreciated by a factor of three, despite only moderate official inflation. More specifi- 
Table 4. Ruble-to-Dollar Exchange Rate, 1989-91

\begin{tabular}{lccc}
\hline Month & $\begin{array}{c}\text { Black market } \\
(\text { buy })\end{array}$ & $\begin{array}{c}\text { Black market } \\
(\text { sell })\end{array}$ & State auction \\
\hline 1989 & & & \\
November & $\ldots$ & $\ldots$ & 10.0 \\
1990 & & & \\
January & $\ldots$ & $\ldots$ & 10.6 \\
February & 10.0 & 18.0 & 12.6 \\
March & 10.5 & 18.0 & $\ldots$ \\
April & 12.0 & 18.5 & 13.8 \\
May & 12.0 & 19.0 & 15.0 \\
June & 12.0 & 19.0 & 17.5 \\
July & 15.0 & 21.5 & 20.6 \\
August & 17.0 & 21.0 & 23.2 \\
September & 16.0 & 20.5 & $\ldots$ \\
October & 16.0 & 19.5 & 20.9 \\
November & 15.5 & 19.5 & 20.9 \\
December & 19.5 & 24.0 & 21.6 \\
1991 & & & \\
January & 28.0 & 35.0 & 25.0 \\
February & 25.5 & 29.5 & 35.1 \\
March & 24.5 & 27.5 & 35.0 \\
April & 28.5 & 31 & 31.7 \\
May & 29 & 31 & $\ldots$ \\
June & 29 & 30 & $\ldots$ \\
\hline Source: Black market rates are from Commersant, various issues. The state auction prices are from Ekonomika $i$ \\
zhizn', various issues. & & & \\
& & &
\end{tabular}

cally, the ruble depreciated steadily through 1990 and then sharply lost value in March 1991, around the time that banknotes with a high face value were withdrawn from circulation, which probably reduced the demand for rubles and created fear of further reforms. Since then, the currency has temporarily stabilized, although the depreciation resumed in the fall of 1991.

Table 5 presents the ratio of state store prices to black market prices for selected commodities in Moscow in December 1990. Black market prices tend to be three to four times higher, although for some commodities the ratio is greater, reaching 19 for medical drugs. One might infer from these figures that a 200 percent price increase would have largely solved the problem of repressed inflation. Commersant reported that some black market prices did indeed fall after the April price reform. Nonetheless, the problem of shortages has not been solved and black 
Table 5. Ratio of Market to State Prices, December 1990, Moscow

\begin{tabular}{lr||lc}
\hline Commodity & Ratio & Commodity & Ratio \\
\hline Drugs & 19.0 & Linoleum & 2.9 \\
Covering wood & 8.9 & Sewing machine & 2.8 \\
Iron & 5.6 & Refrigerator & 2.6 \\
Beef & 4.8 & Rug & 2.6 \\
Men's winter shoes & 4.8 & Color television & 2.5 \\
Women's winter shoes & 4.5 & Children's sweater & 2.4 \\
Automobile & 4.4 & Vodka & 2.4 \\
Women's jacket & 3.7 & Cement & 2.3 \\
Men's sweater & 3.3 & Brick & 2.1 \\
Coffee & 3.0 & Bookcase & 2.0 \\
Tea & 3.0 & Office desk & 1.9 \\
\hline
\end{tabular}

Source: Ekonomika i zhizn' (1991, no. 10).

market prices remain significantly higher than state prices. Moreover, the printing of money has continued in 1991, though prices were fixed after April.

Table 6 reports some indicators of the shortages in the Soviet economy. The table shows the extraordinary reduction of retail inventories of textiles, pointing to how much the "empty shelves" phenomenon has worsened. Unfortunately, we do not have recent data for all goods. Table 7 presents a longer time series on retail inventories for all commodities and reveals a significant drop in retail stocks even before 1990. We do not have a comparable number for 1990, although Ekonomika i zhizn' indicates that inventories fell 14 percent that year. ${ }^{4}$ The numbers on retail inventories, like all the other numbers, point to a severe shortage of goods.

\section{Less Time Spent in the Workplace}

In a planned economy where prices of goods are far below marketclearing levels, goods are allocated through search and queues rather than through markets. ${ }^{5}$ An unofficial Soviet source estimates that 30 million man-years are spent in queues annually-about 25 percent of the waking time of every adult. ${ }^{6}$ This allocation system has been having a

4. Ekonomika izhizn' (1991, no. 17, p. 16).

5. This section on labor supply effects draws on Boycko (1991), Roberts (1991), and Shleifer and Vishny (1991).

6. This information comes from Yuri Dikhanov at Harvard University. 
Table 6. Textile Inventories, January 1991 Relative to January 1990

Percent

\begin{tabular}{ll}
\hline Commodity & $\begin{array}{c}\text { 1991 level } \\
\text { as percent } \\
\text { of } 1990 \\
\text { level }\end{array}$ \\
\hline Socks & 89.6 \\
Leather shoes & 63.0 \\
General clothing & 59.7 \\
Knitwear & 56.2 \\
Silk cloth & 39.1 \\
Wool cloth & 31.5 \\
Cotton cloth & 25.0 \\
\hline
\end{tabular}

Source: Ekonomika i zhizn' (1991, no. 17).

perverse effect on labor supply as repressed inflation and the underpricing of goods relative to time have become more extreme. Suppose that nominal wages rise sharply, as happened in the USSR in the late 1980s, but that nominal prices stay fixed. Then, on the margin, a worker has more incentive to look for goods and less incentive to work for rubles, since increasingly time rather than money is needed to procure goods. As a result, workers will work less and search more. From the social viewpoint, most time spent looking for goods is pure rent seeking and not productive time. Then, as productive labor falls, output falls, and workers are strictly worse off because they get fewer goods with the same total effort spent on working and searching.

What form does the reduction in the labor effort take? One possibility is reduced overtime or greater reliance on part-time jobs, but there are no data to confirm this. More likely, work time is lost through absenteeism and other unofficial forms of taking time off work. In 1990 official measures of "losses of time" in industry and construction were about 50 million man-days, or roughly one day a year per employee in these sectors. Of these, about 10 million man-days were lost to strikes, almost all of which were coal-miners' strikes, ${ }^{7}$ and the rest largely to absenteeism. Ekonomika i zhizn' $(E Z)$ reports that the 50 million man-days is 1.7 times more than the annual average for the $1986-88$ period. However, the magnitude of the time loss is still small and has declined since 1990. For the

7. Gaidar (1991). 
Table 7. Stock of Consumer Goods Measured in Days of Average Retail Sales, 1980-89

\begin{tabular}{lr}
\hline Year & Days \\
\hline 1980 & 96 \\
1981 & 101 \\
1982 & 114 \\
1983 & 116 \\
1984 & 117 \\
1985 & 118 \\
1986 & 108 \\
1987 & 97 \\
1988 & 88 \\
1989 & 80 \\
\hline
\end{tabular}

Source: Åslund (1991, table 1, p. 19).

first quarter of 1991, EZ shows that 1.2 million man-days were lost on strikes, though other losses of time are not reported. Thus, if the official numbers are correct, time loss could have significantly reduced output only through its effect on the coal industry. More likely, most absenteeism is not counted in the government's statistics.

\section{Input Hoarding}

In every open inflation, money loses its function as a store of value and consumers hoard durables (and dollars) as an alternative. Firms, too, switch out of the national currency and hoard inputs to preserve wealth. The preference for real goods over currency becomes even more extreme when people expect an eventual monetary reform. Dollars and durables in such an economy are the only ways to save.

Soviet people probably expect inflation to continue for a while. Cash and saving accounts are no longer an adequate store of value. Holding dollars is illegal, although some underground entrepreneurs undoubtedly save in this way. The most attractive store of value in the USSR is durables-cars, gold, housing for individuals, and inputs for firms. Hoarding is particularly important for firms, which have in recent years found themselves with more cash than they can distribute to workers or invest. Firms hoard their durable inputs, which they can either use or resell later. Over time, durables have become not just a store of value but also a medium of exchange, used by firms to procure both desirable inputs and consumption goods with which to pay their workers. 
Why would firms hoard durable inputs rather than their own output? First, widely used inputs tend to be more generic and hence more liquid. Second, it might be easier to keep the KGB (and the angry public) at arm's length if a firm holds a large input inventory, since it can always argue that this inventory is unusable because complementary inputs are not easily available. Holding a large output inventory, by contrast, exposes a firm to potential penalties from the government as well as to blackmail by those aware of the inventory.

Table 8 presents two sets of estimates of the ratio of input inventories to output inventories over time. The first series is the average of the ratio of firms' input to output inventories. It covers firms producing intermediate as well as final goods. The second series is the ratio of total intermediate-goods inventories to total final-goods inventories. Both series show a substantial increase in the ratio of input to output inventories in the late 1980s. However, the second series rises more sharply, reflecting the particularly short supply of final goods. The Soviet Union seems to be experiencing a sharp decline in the inventories of finished goods, particularly of final goods, and an increased accumulation of intermediategoods inventories, mostly by users rather than by producers. This evidence is consistent with input hoarding. It is also consistent with precautionary hoarding as a way to counter possible future shortages of inputs. Finally, the result is consistent with involuntary hoarding, whereby firms can procure some inputs but not others, which results in large bottlenecks. All these types of hoarding point to coordination failures in the Soviet economy.

The hoarding of durable goods by consumers reduces retail inventories and so raises the cost of the search for goods. ${ }^{8}$ But the hoarding of inputs by firms can do much more damage. When firms hoard inputs rather than produce, output falls. But this problem becomes much worse in the Soviet economy, where a decline in the output of an upstream producer disrupts production downstream. The downstream producers typically have no alternative supply sources, since they are usually closely tied to one producer and there are no organized intermediategoods markets where they can find the inputs they need. Nor can they import the inputs since foreign exchange is also tightly controlled. As a

8. Weitzman (1991). 
Table 8. Measures of Hoarding, 1980-89

\begin{tabular}{ccc}
\hline Year & $\begin{array}{c}\text { Average ratio } \\
\text { of firm input } \\
\text { inventories to } \\
\text { output } \\
\text { inventories }\end{array}$ & $\begin{array}{c}\text { Ratio of total } \\
\text { intermediate- } \\
\text { goods inventories } \\
\text { to total final- } \\
\text { goods inventories }\end{array}$ \\
\hline 1980 & 4.485 & 4.8 \\
1981 & 4.444 & 4.9 \\
1982 & 4.104 & 4.6 \\
1983 & 3.993 & 4.6 \\
1984 & 3.837 & 4.7 \\
1985 & 4.140 & 4.7 \\
1986 & 4.113 & 5.2 \\
1987 & 4.151 & 5.6 \\
1988 & 4.336 & 5.8 \\
1989 & 4.336 & 6.2 \\
\hline
\end{tabular}

Sources: The first column is from Freinkman (1991). The second column comes from Åslund (1991, table 1, p. 19).

result, producers often have to stop production when one of their suppliers is hoarding its inputs.

Such a stoppage is especially costly when the downstream producer has obtained other, less durable inputs that it cannot resell. In the construction industry, whole projects are delayed because some inputs have been sold or stolen while the rest rust or rot on the construction site. Bribes and renegotiation at higher prices can sometimes solve the problem, but such practices are by no means universal. Bribes are illegal, and, in the current environment, it is often unclear whom to bribe or renegotiate with.

\section{Supply Diversion ${ }^{9}$}

Repressed inflation in the Soviet Union created prices that are both highly distorted and extremely low for some goods. Some prices have been gradually liberalized. On January 1, 1991, many wholesale prices were raised and even freed, although producer prices of most "important" commodities are still fixed and even the allegedly free "contract" prices between firms are heavily regulated and linked to state order prices. For many producer goods, free market prices remain much higher than the prices that state enterprises are permitted to pay.

9. The argument in this section is based on Murphy, Shleifer, and Vishny (1991). 
These price distortions give firms a tremendous incentive to fail to honor plans and contracts and to sell output to buyers who pay more. The potential buyers to whom inputs are diverted include cooperatives, illegal enterprises, or even state enterprises that are willing and able to circumvent the rules governing them. Suppliers then simply break their contracts at official prices and divert output to these higher-paying customers. To be sure, many failures to deliver are themselves a consequence of failure to get inputs, but many also result from the ability to sell to competing bidders at higher prices. Unless the buyers can pay higher prices, which they often lack the resources or the legal authority to do, the traditional buyers of the goods simply do not get them. And because Soviet firms typically have no alternative supply sources, the buyers who do not get the inputs must reduce output as well as watch their complementary inputs deteriorate. In these ways, supply diversion has the same adverse consequences as input hoarding.

Supply diversion takes several forms. One common form is selling goods to parties that pay more rather than delivering them to the contracted buyers. The head of a large oil distribution concern has recently complained that refineries are selling their oil to cooperatives that then resell it to consumers at three times the state price, with the result that official users are experiencing acute shortages. ${ }^{10}$ Another important form of diversion is barter. Instead of delivering their products for cash or enterprise funds to the planned or contracted recipient, firms sometimes barter the output for commodities that their workers want, including food and consumer durables. The fantastic growth of commodity exchanges in the USSR, in which most trades take the form of barter, testifies to the importance of this form of transaction. Barter, however, is severely limited because the rate of exchange in barter is also supposed to be governed by official relative prices, which makes it extremely hard to find a trading partner. Even when mutual coincidence of wants at official prices does exist, firms often cannot complete the trade because they cannot access the state transportation network. One other important form of diversion is theft. $E Z$ reports that theft of state property rose by almost one-third from 1989 to 1990 and then rose 39 percent between the first quarters of 1990 and $1991 .{ }^{11}$ The increased theft of state

10. Sovetskaia Rossiya, May 15, 1991, p. 2.

11. Ekonomika i zhizn' (1991, nos. 5 and 17). 
Table 9. Indicators of Supply Diversion, 1987-91

\begin{tabular}{ccc}
\hline Period & $\begin{array}{c}\text { Volume of unfilled } \\
\text { deliveries in } \\
\text { billions of rubles } \\
\text { (state prices) }\end{array}$ & $\begin{array}{c}\text { Percent of } \\
\text { enterprises failing } \\
\text { to meet con- } \\
\text { tractual obligations }\end{array}$ \\
\hline 1987 & 3.1 & 23 \\
1988 & 2.2 & 17 \\
1989 & 1.1 & \\
First quarter & 2.8 & 9 \\
Second quarter & 3.3 & 14 \\
Third quarter & 3.4 & 21 \\
Fourth quarter & & 19 \\
1990 & 2.5 & 13 \\
First quarter & 2.8 & 18 \\
Second quarter & 5.8 & 25 \\
Third quarter & 6.6 & 25 \\
Fourth quarter & & \\
1991 & 10 & 24 \\
First quarter & & \\
\hline
\end{tabular}

Source: Izvestiia, various issues, and Narodnoye Khozaistvo SSSR, various issues.

property might simply reflect shortages, but it also may indicate better opportunities for market resale.

Table 9 presents two measures of supply diversion. The first series shows the volume of unmet deliveries, measured as the ruble value of deliveries that were contracted for but not made. The value rises from 2 billion rubles in 1988, to 17.7 billion rubles in 1990 , and 10 billion rubles in the first quarter of 1991. Although the nominal value of the 1991 figure might, in part, reflect the higher wholesale prices used in the calculation, the growth is impressive nonetheless. The second series is the fraction of enterprises failing to meet their contract commitments. Its value rises from 17 percent in 1988 to 25 percent in the last two quarters of 1990. For the first quarter of 1991, according to the paper Izvestiia, the largest number of enterprises failing to meet their contract commitments were in the chemical and timber complex, with slightly fewer in the metallurgical complex; the fuel and energy complex and the machinebuilding complex also had substantial numbers of firms not meeting their commitments. ${ }^{12}$ The paper concludes that the breakdown of economic ties is having "the most pernicious effect" on contract discipline.

12. Izvestiia, May 15, 1991. 
In the distorted Soviet economy, people who can pay the most for the inputs, and thus get them, are not necessarily the ones who value these inputs most. When consumer goods are diverted from the retail sector and resold privately, one usually thinks that consumers who value these goods most highly are the ones who buy them. But with inputs the story is more complicated. Producers who most value some inputs may not have the cash to purchase them, or may not have the sought-after items to barter for these inputs, or may be prevented from legally participating in the market competition for inputs. Absent equal access of all buyers to the market for goods, there is no reason to believe that output diversion to those who pay more raises efficiency and output. Having some market transactions when most activities are coordinated through plan can actually reduce output.

Evidence from the construction industry suggests that disruptions associated with the diversion of inputs are large. Table 10 reports the ratio of new capacity introduced into operation to construction investment outlays in the Soviet Union. Construction is a good example of an industry that would greatly suffer from supply diversion, since it is not vertically integrated, relies on a large number of inputs, and competes for many of the scarce inputs with private builders. Construction investment has been falling sharply in the USSR in the past few years, which suggests that, because of production lags, the ratio of newly installed capacity to investment should rise. In fact, the table shows that it has been falling rapidly, from almost 100 percent in 1980 to 86 percent in 1990 . Moreover, most of the decline has occurred since 1988, when the reforms started. In the first quarter of 1991, this ratio was 41 percent, down from 51 percent in the first quarter of 1990 . These numbers from the construction industry, which are viewed with great concern by the Soviet government, are a clear indication of bottlenecks and coordination problems that undoubtedly are reducing output.

In sum, the collapse of the Soviet economy is at least in part explained by the breakdown of traditional coordination channels and the resulting diversion of labor and inputs. Such diversion directly reduces output, but also leads indirectly to the breakdown of downstream production. These coordination problems make us wonder why Soviet output has not fallen even more; they certainly invite no optimism about a spontaneous reversal of the collapse. 
Table 10. New Capacity Installed Relative to Capital Outlay (Measured in State Prices), 1980-91

\begin{tabular}{ll}
\hline Year & Ratio \\
\hline 1980 & 0.987 \\
1981 & 0.955 \\
1982 & 0.971 \\
1983 & 0.974 \\
1984 & 0.976 \\
1985 & 0.962 \\
1986 & 0.940 \\
1987 & 0.950 \\
1988 & 0.882 \\
1989 & 0.864 \\
1990 & 0.863 \\
$1991: 1$ & 0.411 \\
\hline
\end{tabular}

Source: Freinkman (1991); Ekonomika i zhizn', various issues.

\section{Implications for Policy}

If our diagnosis of the Soviet Union's problems is correct, the economy is likely to decline further. The republics are likely to experience severe trade tensions and even trade wars, which will aggravate the coordination problems. Some republics will introduce their own currencies, which will put even more pressure on the ruble. With no budget controls, the ruble, as well as some republican currencies, might hyperinflate. Policies to reverse the collapse of the Soviet economy must restore economic coordination and stop money printing. In this section, we first discuss what policies these might be and then suggest ways of implementing them.

\section{Price Reform}

Economic coordination can be achieved with either a tight plan or an effective market. If the central authorities could use commands to enforce labor "discipline," prevent input hoarding, and avert supply diversion, they could reduce the severity of the coordination breakdown. Central command, however, has many disadvantages. First, even if it reverses the economic collapse, it is incompatible with long-run liberalization. Second, a return to tight plan enforcement is likely to fail. The 
state plan enforcement apparatus, notably the Communist party and the KGB, were weakening even before the August coup and were largely dismantled after it failed. No one is left, then, to enforce the plans, and the public does not want to bring back the enforcers. Third, and most important, the control of economic policy has moved from the center to the republics, and the republics show no interest in giving power back to the center. The return to tight central planning is infeasible.

An alternative solution is to greatly expand market allocation of goods throughout the economy, particularly of intermediate goods. Conversion to markets would require the complete replacement of state orders for goods with contracts between enterprises at completely free prices. The key feature of this system would be equal access by all firms to the competition for inputs. This could be accomplished through the commodity exchanges that are now prospering in many regions or through longer-term market mechanisms that exist in the West. Perhaps most important, this competition should take place between the republics as well as within them because restrictions on interrepublican trade are certain to devastate the economy.

To create reasonable access by all firms to scarce inputs, all firms must have information on what inputs are available as well as have the ability to transport them. Today, lack of access to railroads is one of the main impediments to transactions between enterprises. Private businesses usually use trucks, which are inefficient and unreliable. Access to transport is critical for the market allocation of inputs and should be one of the first steps of the reform process.

\section{Monetary Reform}

Price liberalization risks a hyperinflation. Firms are effectively controlled by workers, who will undoubtedly succeed in raising wages as prices increase. A fairly standard hyperinflationary spiral could result. Although a hyperinflation is not the worst thing that could happen to the Soviet economy-it might speed up reforms and clear out the old money-it has large costs. To avoid a hyperinflation, price liberalization must be accompanied by monetary and fiscal discipline, a policy that will prove extremely difficult because the republics currently have no budget and the central government is collecting almost no revenue. 
Price liberalization may itself be the most important step toward fiscal tightening, since a tremendous fraction of the state budget is devoted to price subsidies.

Monetary stabilization is essential to avoid a hyperinflation. It has several other benefits as well, including an increase in the attractiveness of money as a store of value. But price liberalization is a critical step even if monetary restraint proves elusive. For even if price reform leads to rapid open inflation in the republics, many of the distortions of the current repressed-inflation regime will be removed. For example, money will recover its use as a medium of exchange, with the result that transactions for cash will replace inefficient barter. Moreover, as argued earlier, the incentive to hoard inputs is weaker in an open inflation than in a repressed inflation. Apart from all the other efficiency benefits that will result from a move to the market pricing and allocation of goods, it pays to convert a repressed inflation into an open one.

Monetary stabilization is virtually certain to take place at the republican level. Republics will undoubtedly introduce their own currencies. One reason for this is nationalism. More important, once one republic introduces its own currency and removes rubles from circulation, other republics face an enormous pressure to follow suit to prevent rubles that are no longer legal tender in the first republic from being spent in their own territories. The only Nash equilibrium in currency reforms is for everyone to have them. From the point of view of achieving monetary control, the introduction of new currencies by the republics seems quite attractive. First, it will get rid of the ruble, perhaps through a hyperinflation. Second, republican currencies will place responsibility for monetary stability with republican governments, which unlike the center have actually retained some taxing authority. In the intermediate run, then, the breakup of the USSR might have actually encouraged price stability. The combination of price liberalization and monetary stabilization will provide the economies of the successor states to the Soviet Union with a much more efficient allocation system than the one that currently exists. When money rather than time begins to buy goods and when lines disappear, people will likely work more than they do now. Monetary stabilization and elimination of queues are also likely to eliminate the incentives to hoard that now affect both consumers and enterprises. With market allocation of goods, the diversion problems that 
plague the Soviet economy today are likely to become less severe. Assuming that the market infrastructure is allowed to work, the collapse of output might be reversed.

\section{Getting from Here to There}

It is clear that price liberalization is the right policy for the former Soviet Union; it is much less clear how to achieve it. Many republics today are run by populist politicians wary of reforms that bring significant short-run hardships. Recall that Premier Prunskiene, a reform-minded leader of Lithuania, was fired by her own people in early 1991 when she advocated price reforms. The public is skeptical about market reforms, in part, because people are poor and do not want more hardship and, in part, because they are not convinced that capitalism is the way to go. Finally, even after the failure of the August coup, the bureaucrats who still run the economy often oppose reform because it will take away their official privileges.

In practice, this implies that reforms are likely to be slow and not always strongly market oriented. Conditional Western aid can be a potent force in getting the republics to move toward the market. The sharp fall of the Soviet economy makes some kind of aid virtually inevitable. But will this aid be a stopgap measure, which will only delay reforms, or will it actually speed up market reforms? How can aid be structured to achieve the latter?

To promote faster market reforms, the West should aid the republics rather than the center. This means, to start, recognizing the republics as sovereign states, admitting them to the World Bank and the International Monetary Fund, and otherwise encouraging sovereignty. This also means negotiating structural adjustment aid as well as humanitarian aid directly with the republics rather than with the central government in Moscow and dealing with the republics in matters of trade and foreign direct investment.

For many reasons, aid to the republics will accelerate market reforms. First, the elected republican leaders, and not the central government, have the power and authority to propose and implement changes in their local economies. As the example of Poland illustrates, the transition to markets requires many sacrifices from a country's citizens. Without Lech Walesa's commitment to reforms, a move toward the free mar- 
ket might not have been possible in Poland. The Soviet Union today has no popular national leader like Walesa. Few people would accept sacrifices brought about by reforms initiated by Mikhail Gorbachev. In fact, a Moscow stamp on a reform proposal is probably a near-fatal blow against it. To promote reform, the West should direct aid to the republics, whose leaders can actually energize their people to change.

Second, dealing directly with the republics will allow aid to be tailored to each region's needs. When a republic is ready to privatize, the West can work with it on a privatization program. When one wants substantial foreign direct investment and can promise the security of foreign property, the West can work out with that republic the guarantees of such security. If a republic decides that it wants to go slowly and that it does not mind socialism after all, the West can refuse aid. By dealing directly with the republics, the lenders can design aid packages most conducive to reform.

Third, and most important, dealing with the republics will give the West a great deal more leverage in making sure that reforms do take place. If one republic reforms and another does not, the West can tilt the aid toward the one that is making changes. Fostering competition between republics for aid is certain to speed up reform. After all, the best thing the Soviet republics have to offer the West in exchange for aid is rapid reform. If, by contrast, aid is centrally directed, there will be endless negotiations and compromises, with the West having few options but to bargain with Moscow bureaucrats-a sure way to slow down reform.

Channeling aid through Moscow also means dealing with a committee of republican leaders, some of whom want to reform faster than others and all of whom want a slice of the same pie and will bargain, rather than compete, for a bigger slice. Dealing with such a committee is certain to delay, maybe derail, critical reforms.

Even apart from competition for aid, other strong competitive forces begin to work when republics pursue reforms independently. If Ukraine liberalizes its prices but Belorussia does not, resources will flow from Belorussia to Ukraine. Belorussian farms and firms will sell their crops and products in Ukraine, where prices are free, rather than in Belorussia, where they are controlled. Ukrainians then get the goods, while Belorussians get the worthless rubles. As a result, shortages in Belorussia will get worse, while shortages in Ukraine will disappear. This flow 
of goods out of Belorussia will put tremendous pressure on its government to free up prices so that its people can consume the output of its firms and farms. If Western aid can get the ball rolling in some regions, other regions will face a strong incentive to liberalize too.

Unfortunately, another response to competition is to close borders, so that a republic's products cannot escape. The typical Soviet republic believes that it is subsidizing the others. As shortages become more severe, trade wars between republics are a genuine risk, especially if some liberalize faster than others. Such trade wars will devastate the extremely interdependent republican economies. One hopes that the consequences of trade wars will themselves dissuade even nationalist republican leaders from starting them. But if that is not enough, Western aid might become critical for resolving conflict, through facilitating trading arrangements and turning against any region or republic that tries to interfere with trade. Like the Marshall Plan in Western Europe, aid to the Soviet republics should be conditional on liberal trade policies.

There is no guarantee that economic reform at the republican level will be strictly better than reform originating from the center. Many republics will try their own economic experiments guided by nationalism and populism rather than by economic principles. As republics introduce their own currencies, some will experience rapid inflations or even hyperinflations. As some republics begin to free prices, trade wars and perhaps even hotter conflicts with their neighbors will flare. Despite these concerns, it is better to direct aid to republics, where the authority and the will to reform actually reside. 